\title{
Deep and disturbed: conditions for formation and eruption of a mingled rhyolite at Ascension Island, south Atlantic
}

\author{
Katy J. Chamberlain ${ }^{\star \alpha, \beta}$, Jenni Barclay $\gamma$, Katie Preece $\delta$, \\ Richard J. Brown ${ }^{\epsilon}$, Iona McIntosh ${ }^{\alpha}$, EIMF $^{\zeta}$ \\ ${ }^{\alpha}$ Institute for Marine Geodynamics, Japan Agency for Marine Earth Science and Technology, Yokosuka 237-0061, Japan \\ $\beta$ School of Environmental Sciences, University of Derby, Derby, DE22 1GB, UK \\ $\gamma$ School of Environmental Sciences, University of East Anglia, Norwich, NR4 7TJ, UK \\ ${ }^{\delta}$ Department of Geography, College of Science, Swansea University, Swansea, SA2 8PP, UK \\ ${ }^{\epsilon}$ Department of Earth Sciences, Durham University, Durham, DH1 3LE, UK

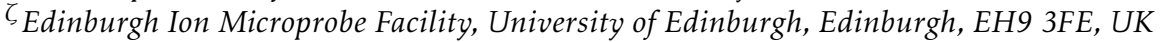

\begin{abstract}
The generation of felsic melts (through open or closed system processes) within ocean island volcanoes has been a key area of study since their identification. At Ascension Island in the south Atlantic, explosively erupted felsic melts have, to date, demonstrated a marked absence of signs of magma mixing and crustal assimilation. Here we present the first observations of a fall deposit from Ascension Island recording both macro- and micro-scale evidence for magma mingling. Geochemical analyses of mineral and glass phases, coupled with volatile concentrations of melt inclusions highlight the role of lower-crustal partial melting to produce rhyolitic magmas. Glass textures and the lack of zoning in major mineral phases indicate that mingling with a mafic melt occurred shortly prior to eruption. These inferences of a deep rhyolite production zone, coupled with rapid ascent rates highlight the challenges in forecasting a similar style of eruption at Ascension Island in the future.
\end{abstract}

Keywords: Magma mingling; Ascension Island; Crustal melting; Magma genesis

\section{InTRODUCTION}

The evolution and eruption of felsic magmas has been a focus of significant research for many years [e.g. Carmichael 1964; Hildreth 1981; Smith and Bailey 1966]. Felsic melt generation at ocean island volcanoes, that are unrelated to plate tectonic boundaries, are important locations for study because they form and evolve felsic melts within thin ocean crust [e.g. Ablay et al. 1998; Bohrson and Reid 1995; Carley et al. 2011; Carracedo et al. 2007; Geist et al. 1995; Geist et al. 1988; Harpp and White 2001; Koppers 2005; Macdonald et al. 1987; Mancini et al. 2015]. The dominant composition of melts erupted in these settings, and the volumes of melt produced, can vary greatly. For example, Hawaiian volcanism is dominantly basaltic with only minor trachytic compositions [Frey et al. 1990; MacDonald and Katsura 1964] with a shield-stage vertical accumulation rate of $8.6 \mathrm{~km} \mathrm{Myr}^{-1}$ for Mauna Kea [e.g. Sharp and Renne 2005]. By contrast, the Canary Islands have erupted significantly higher proportions of felsic melts [e.g. Ablay et al. 1998; Schmincke 1976] but have lower vertical accumulation rates: $0.6 \mathrm{~km} \mathrm{Myr}^{-1}$ for La Gomera [Paris et al. 2005]. Lower-flux ocean islands produce larger proportions of felsic melts [e.g. Brenna et al. 2015; Chamberlain et al. 2019; Jeffery

${ }^{*}$ Corresponding author: k.chamberlain@derby.ac.uk and Gertisser 2018]. These felsic melts commonly have higher water concentrations and melt viscosities and have a greater potential for hazardous explosive activity affecting areas distal even to the vent. Understanding the genesis and eruption triggering mechanisms for felsic melts therefore presents an important challenge for hazard assessment.

Ascension Island is an example of a lower magmatic flux ocean island [Minshull et al. 2010]. Previous work suggests that the majority of its felsic melts are produced through closed-system crystal fractionation [Chamberlain et al. 2019; Chamberlain et al. 2016]. However, a recently discovered mingled fall deposit cannot be explained by simple crystal fractionation alone. This deposit provides exceptional evidence for magma mingling prior to eruption. Magma mixing (chemical equilibration) and mingling (physical mixing of two magmas of distinct viscosities) are processes capable of triggering eruptions [e.g. Leonard et al. 2002; Morgavi et al. 2017; Nakamura 1995; Sparks et al. 1977]. The identification of this mingled fall deposit allows new insights to be generated into the nature of the magmatic plumbing system and the origin of evolved melts at Ascension Island, and importantly, the timescales of magma transfer and mingling prior to eruption.

Here we present detailed field observations, whole 
rock chemistry, and petrographic data from the mingled fall deposit from Ascension Island. These data highlight the bimodal composition of the juvenile material and reveal evidence for magma mingling preserved on a macro- and microscopic scale. These observations, coupled with melt inclusion volatile data, identify the role of magma mingling in triggering the eruption of the rhyolite. This rhyolite was itself produced at depths close to the Moho, with implications for ascent rate of magmas during future eruptions at Ascension Island, and other low flux ocean islands.

\section{Magmatism at Ascension Island}

Ascension Island is an ocean island volcano located at $7^{\circ} 56^{\prime} \mathrm{S} ; 14^{\circ} 2^{\prime} \mathrm{W}$, within $100 \mathrm{~km}$ of the large tectonic structures of both the Mid Atlantic Ridge (MAR) and the Ascension Fracture Zone (AFZ) (Figure 1). It has a resident population of around 800 people. Volcanism began 5-6 Ma [Klingelhöfer et al. 2001; Minshull et al. 2010], but subaerial volcanism began only at $\sim 1 \mathrm{Ma}$ (from Ar-Ar dating, [Jicha et al. 2013]). Recent studies have shown that the island is still active, with the most recent eruption dated to $0.51 \pm 0.18 \mathrm{ka}$ [Preece et al. 2018].

Ascension Island volcanism is the product of a transitional to mildly alkaline magmatic series of olivine basalt - hawaiite - mugearite - benmoreite - trachyte - rhyolite. Previous workers have hypothesised that volcanism results from melting of an enriched mantle component that passed across the MAR, and allowed volcanism to continue off-axis [Paulick et al. 2010]. These melts are then modified by various degrees of fractional crystallisation upon ascent, in discrete magma storage zones, with minor amounts of mineral accumulation from older plutonic bodies within the upper crust [Chamberlain et al. 2019; Chamberlain et al. 2016; Kar et al. 1998] to produce the wide compositional range of erupted products at Ascension Island (between 47 and 72 wt. $\% \mathrm{SiO}_{2}$ [Chamberlain et al. 2019]). Whilst there is evidence for periodic stalling and minor assimilation of crustal material to generate more evolved compositions, there has been little evidence for interaction between different magmatic types in any of the Ascension Island rocks [Chamberlain et al. 2019; Chamberlain et al. 2016].

\section{The Mingled fall DePOSIT}

More than 70 explosive eruptions of felsic magma have occurred in the $\sim 1$ Myr subaerial history of Ascension Island, but, to date, only one preserves macroscopic evidence of magma mixing in juvenile clasts. This mingled fall deposit outcrops in a few localities in the older central felsic complex. It has a maximum thickness of $1.5 \mathrm{~m}$. It has complex internal stratigraphy (Figure 2) that includes both lithic clast-dominated units (L1A and L1B: variably present; up to $26 \mathrm{~cm}$ thick, combined), pumice-dominated units (L2: between $13 \mathrm{~cm}$ and $70 \mathrm{~cm}$ thick) and scoria-dominated units (L3: 36 $\mathrm{cm}$ to $127 \mathrm{~cm}$ thick; top rarely preserved), which hint at complex magmatic and eruptive processes. It is generally moderately sorted, though this varies throughout the unit, and between localities, perhaps reflecting proximity to the vent (of unknown location). Only one complete section through the mingled fall deposit has been found (Figure 2) in which all eruptive subunits are present. In many cases the ashy base (A) and L1 subunits are not present (Figure 2).

At some localities the first subunit is a white ash-rich layer (subunit A), 1-10 cm thick, with a planar or undulatory top. This overlies different units dependent on the location, but commonly it overlies reworked pumice deposits. There is no evidence for a time break (e.g. a palaeosol or erosion surface) between subunit A and the lithic clast-dominated layer above it (L1). Subunit L1A is a well-sorted, dense, scoria fall deposit, that coarsens upwards from $\sim 1 \mathrm{~mm}$ to $\sim 3 \mathrm{~mm}$ grainsize, (Figure 2). Scoria clasts are sub-rounded and poorly vesicular. Lithic clasts are $\sim 25 \%$ by total volume and are dense black mafic lavas, their oxidised equivalents, and minor trachyte lava. A $\sim 5 \mathrm{~mm}$-thick layer of finegrained mafic ash cap tops this subunit. Subunit L1B is moderately well sorted, coarsens upwards from $\sim 3 \mathrm{~mm}$ to $\sim 10 \mathrm{~mm}$ (Figure 2 ). Lithic clasts are $\sim 25 \%$ by volume of the subunit, and are dense mafic lavas, coarsely crystalline plutonic clasts (dominantly syenitic) and rare pink rhyolite lava (hereafter all percentages refer to percent by volume on a total volume (i.e. not DRE) basis). The grey mafic scoria is still dense, with limited visible vesicularity. The L1/L2A boundary marks the appearance of highly vesicular white pumice and denser light grey pumice. At the base of L2A clasts of dense grey scoria dominate $(\sim 65 \%$ of the volume of the deposit) with subordinate grey pumice $(\sim 20 \%)$, white pumice $(\sim 10 \%)$ and lithic clasts $(\sim 5 \%)$. This changes gradationally through the unit where the top of L2A is dominated by the white pumice ( $60 \%$ by volume) with subordinate dense grey scoria (18\%), grey pumice $(12 \%)$, and lithic clasts $(10 \%)$ at the top of L2A. Most pumice clasts contain small mafic blebs or exhibit mixing textures between scoria- and pumice-looking material (Figure 3A). The pumice clasts contain phenocrysts of feldspar and pyroxene up to $1.5 \mathrm{~mm}$ in diameter and account for $\sim 10 \%$ by volume (including vesicles) of the pumice clasts. A decrease in clast size marks the boundary between subunits L2A and L2B. L2B contains only rare grey pumice and consists dominantly of highly vesicular pumice clasts, with minor dense scoria at the base. L2B coarsens upwards and is moderately well-sorted. Lithic clasts account for $\sim 10 \%$ of the volume of this subunit and are dense mafic lavas (oxidised and unoxidised). At the top of L2B a new highly vesicular scoria clast type appears and accounts for $\sim 10 \%$ of the volume of the subunit at the top of L $2 \mathrm{~B}$. The bound- 


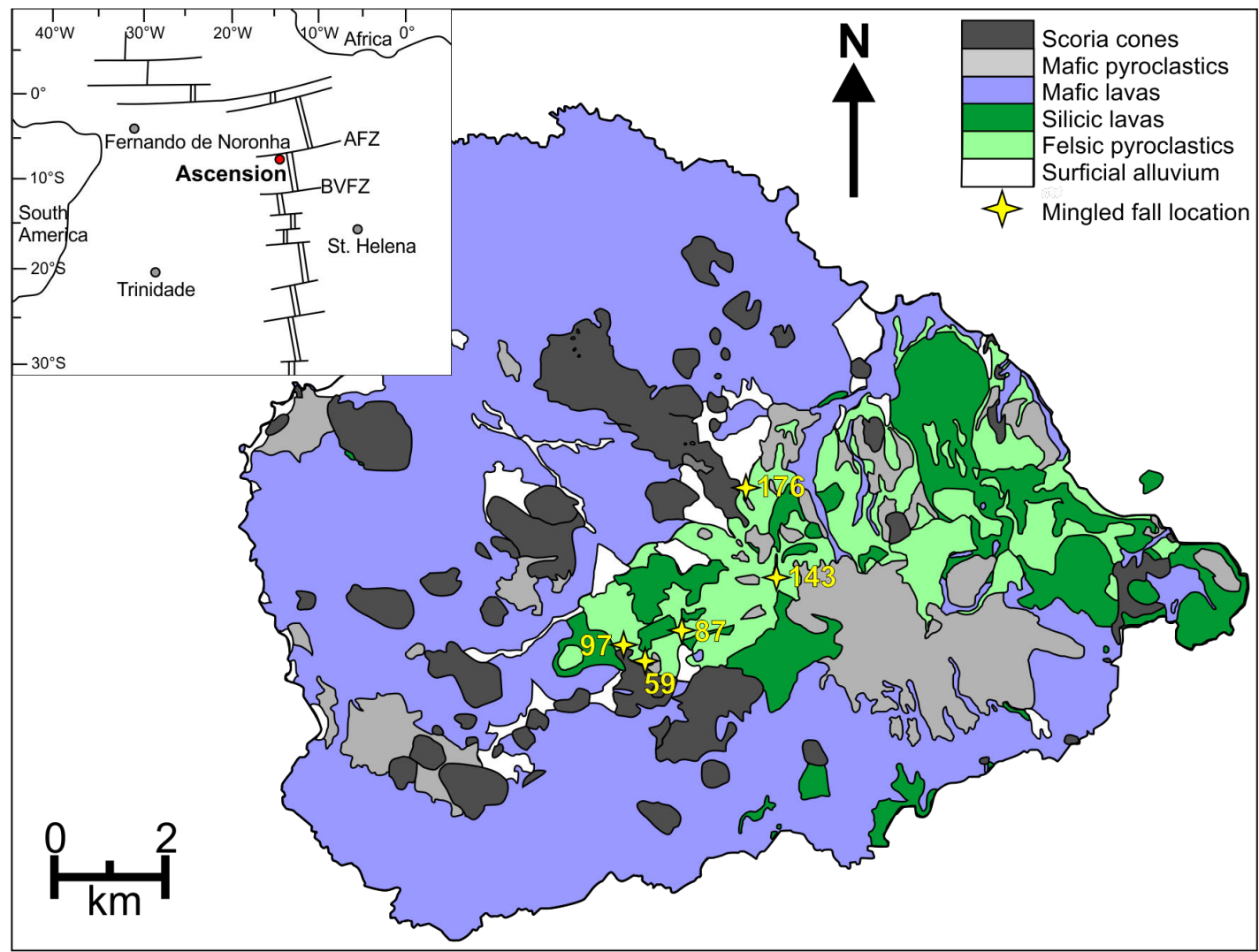

Figure 1: Geological map of Ascension Island adapted from Chamberlain et al. [2019] showing the location of the mingled fall deposit (yellow stars). Numbers in yellow relate to deposit thickness in $\mathrm{cm}$. Inset shows the location of Ascension relative to the Ascension Fracture Zone (AFZ) and the Boca Verde Fracture Zone (BVFZ).

ary between L2B and L3 is diffuse over $\sim 2 \mathrm{~cm}$. L3 is a scoria fall deposit composed (by volume) of $\sim 75 \%$ highly vesicular black scoria (Figure 3B), $10 \%$ white pumices with macroscopic mixing textures and $15 \%$ lithic clasts. L3 is characterised by the appearance of large plutonic lithic clasts (of syenitic to granitic composition), commonly coated in mafic volcanic rock, and significantly larger in size than the juvenile scoria clasts (Figure 3C). These lithic clasts help to distinguish this eruptive deposit from other units on the island. Other lithic clasts present include dense mafic lavas (oxidised and unoxidised) and rare pink rhyolitic lava.

\section{Methods}

Bulk samples were collected at the two key stratigraphic intervals, at two locations, that represent the scoria and pumice end-members clast types in the mingled fall deposit (units L2B and L3; Figure 2). Samples were sieved to $>8 \mathrm{~mm}$ or $>16 \mathrm{~mm}$ as appropriate, to leave more than fifty juvenile clasts in each bulk sample. Clasts were picked by hand, separated, and cleaned by removing adhering matrix or oxidised rinds by hand followed by soaking in frequently changed milli-RO water for a minimum of one week. Samples were then dried thoroughly at $60^{\circ} \mathrm{C}$ prior to crushing.
An aliquot of the sample was selected to mill for whole rock X-ray fluorescence (XRF) analysis at the University of East Anglia (UEA) using a Brucker-AXS S4 Pioneer. The remaining majority of the sample was bulk crushed by hand, before being sieved into various size fractions $(<2 \mathrm{~mm})$. Minerals and glass separates were handpicked from the $0.5-1 \mathrm{~mm}$ size fraction, mounted into low-activity epoxy discs, and polished to expose melt inclusions and mineral cores. Melt inclusion-bearing minerals were imaged using reflected light microscopy prior to analysis. Following the method of Humphreys et al. [2006a] for melt inclusion analyses, secondary ion mass spectrometry (SIMS) measurements of selected volatile and trace elements were made prior to measurement of other major and trace elements by electron probe microanalysis (EPMA) and laser ablation inductively coupled plasma mass spectrometry (LA-ICPMS).

Mounts of melt-inclusion bearing minerals were gold-coated and analysed using SIMS for isotopes of volatile $(\mathrm{H}$ and $\mathrm{C})$ and key trace elements $(\mathrm{Li}, \mathrm{Be}, \mathrm{B}$, F, Mg, Si, S, Cl, Rb, Sr, Zr, Nb, Ba) using a Cameca ims-1270 ion microprobe at the NERC Ion Microprobe Facility at the University of Edinburgh (UK). During analysis, the primary beam was rastered for $120 \mathrm{sec}-$ onds over an area of about $35 \times 45 \mu \mathrm{m}$ prior to first data acquisition to remove the gold coat and any possible surface contamination. Secondary ions were then 


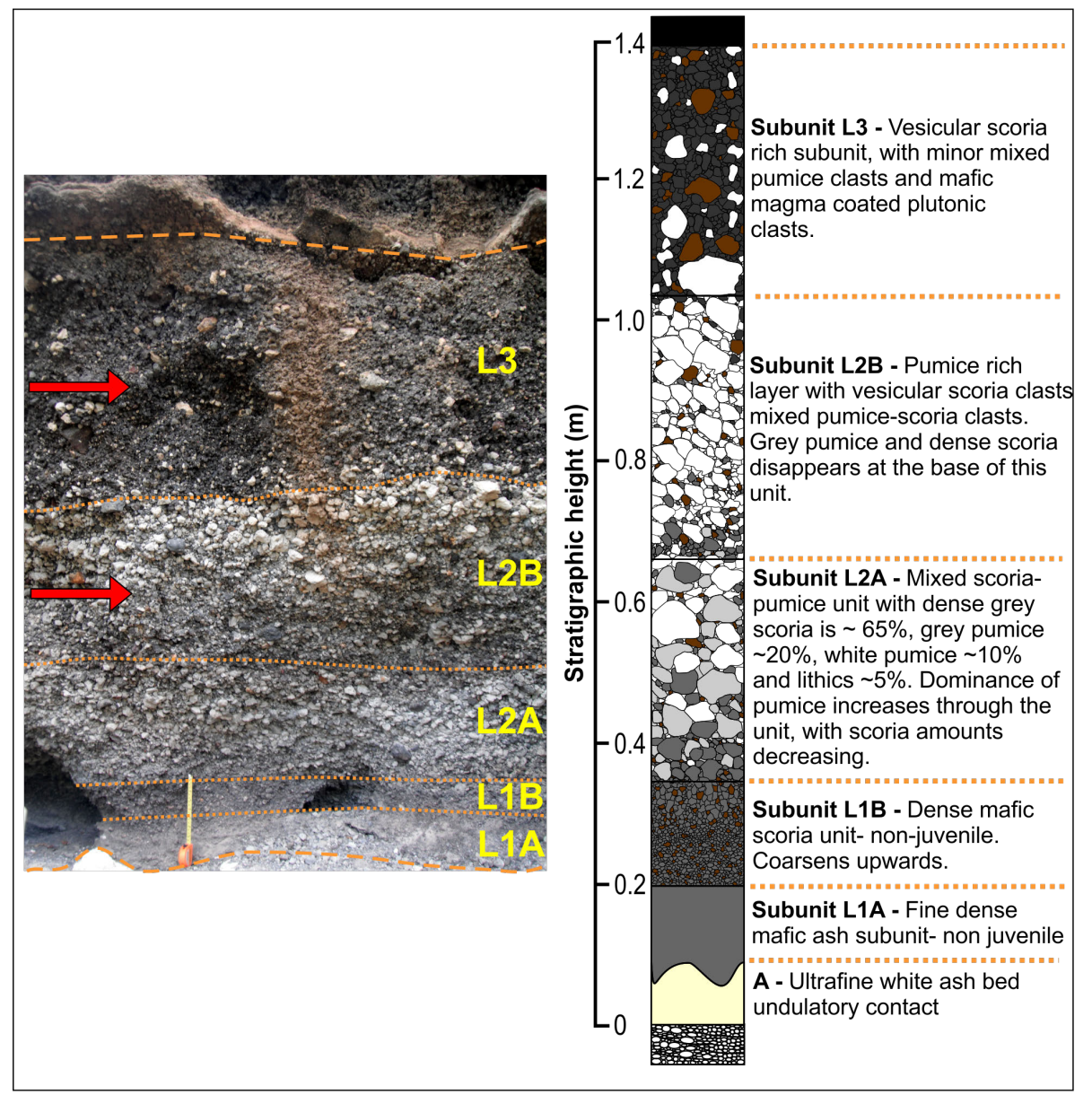

Figure 2: The mingled fall deposit of Ascension Island. Sample locations shown by the red arrows, and subunits labelled as A, L1A, L1B, L2A, L2B, L3. Tape measure is extended to $20 \mathrm{~cm}$ for scale.

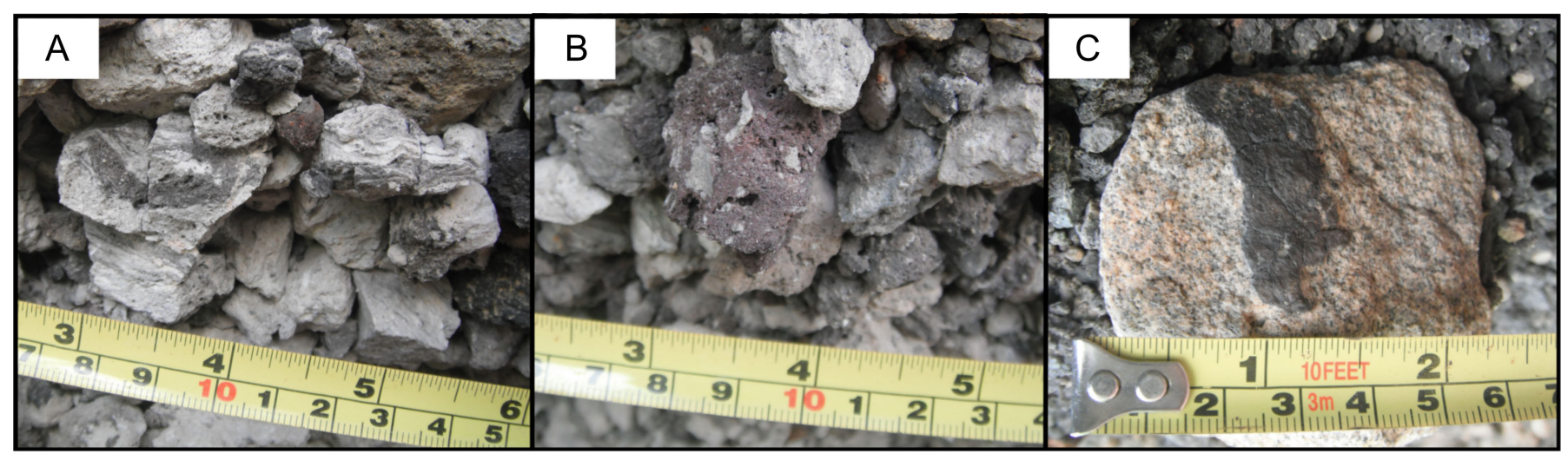

Figure 3: Clasts of the mingled fall deposit. [A] Mingled felsic clasts from subunit L2B; [B] Mingled scoria clasts from L3; [C] Mafic volcanic rock-coated plutonic clast from subunit L3. Tape measure shows distances in inches (top) and centimetres (base).

sputtered from melt inclusions with a 5-6 nA primary ${ }^{16} \mathrm{O}_{2}{ }^{-}$beam focused to a $\sim 25 \times 35 \mu \mathrm{m}$ spot. The area analysed was reduced using a (field) aperture to accept only the central $20 \mu^{2}$ of the bombarded area. Analyses were done in two parts; initially volatiles $\mathrm{H}, \mathrm{C}, \mathrm{F}$, $\mathrm{S}$, and $\mathrm{Cl}$ (plus Si) followed by traces $\mathrm{Li}, \mathrm{Be}, \mathrm{B}, \mathrm{Rb}, \mathrm{Sr}$, $\mathrm{Zr}, \mathrm{Nb}$ and $\mathrm{Ba}$ (plus majors $\mathrm{Mg}$ and $\mathrm{Si}$ ) in the same hole. The mass resolution employed $(M / \Delta M>2500)$ was sufficient to fully resolve ${ }^{12} \mathrm{C}^{+}$from ${ }^{24} \mathrm{Mg}^{2+}$, and ${ }^{32} \mathrm{~S}^{+}$from ${ }^{16} \mathrm{O}_{2}{ }^{+}$. Standards used were NIST SRM610, StHS6/80-G, T1-G, and Lipari obsidian using preferred values from GeoReM [see Jochum et al. 2005] for trace elements, and Lipari glasses for $\mathrm{H}_{2} \mathrm{O}$ [Mangan and Sisson 2000] with a $20 \%$ correction to higher values [Sisson, pers. comm.], RB497 for $\mathrm{CO}_{2}$ [Brooker et al. 1999], NIST SRM610 for S, and Lipari (from GeoReM), and 
USGS A and T glasses for halogens, respectively.

In situ major element analyses were obtained by EPMA using a CAMECA SX100 at Edinburgh University using wavelength-dispersive spectrometry. Beam size varied between 1 and $5 \mu \mathrm{m}$ depending on the element being analysed. Only glass analyses with totals of $<93 \mathrm{wt}$. \% were excluded, due to their known high water concentration; values for the remaining glass analyses were then normalised to $100 \%$. Prior to analysis, back-scattered electron (BSE) images were taken of all melt inclusions and mineral phases to identify zoning patterns and locate analytical spots. This was carried out at UEA using a JEOL JSM 5900LV scanning electron microscope (SEM). Trace element analyses of mineral phases and matrix glass were obtained at the University of Durham using a New Wave deep UV laser (193 $\mathrm{nm}$ solid state) coupled to an X-series 2 ICPMS. Analyses were run using a $35 \mu \mathrm{m}$ spot. The LA-ICPMS data were internally normalized to ${ }^{29} \mathrm{Si}$ or ${ }^{43} \mathrm{Ca}$ from EPMA analyses. Abundances of single trace elements were calculated relative to a bracketing standard (NIST 612), which was analysed throughout the run under identical conditions. Precision and accuracies varied depending on the analytical conditions but generally have $<10 \%$ ( 2 s.d.) uncertainties (see Figures 5, 6 and 7 for uncertainties).

\section{Results}

\subsection{Whole rock data and petrography}

Whole rock compositions of the scoria and pumice clasts from unit L2A and L3 are clearly bimodal (Figure 4). The scoria is trachy-basaltic in composition and the pumice is trachytic. Whilst every care was taken to separate end members of non-mingled pumice and scoria sub-millimetric-scale mingling textures observed in BSE images suggest that this is unlikely to have been completely successful (Figure 5). Scoria material is enriched in $\mathrm{TiO}_{2}, \mathrm{Al}_{2} \mathrm{O}_{3}, \mathrm{MgO}, \mathrm{Fe}_{2} \mathrm{O}_{3}, \mathrm{CaO}, \mathrm{P}_{2} \mathrm{O}_{5}, \mathrm{Ba}, \mathrm{Sr}$, $\mathrm{Sc}$ and $\mathrm{V}$ relative to the pumice material. Pumice clasts are in turn enriched in $\mathrm{SiO}_{2}, \mathrm{~K}_{2} \mathrm{O}, \mathrm{Rb}, \mathrm{Th}, \mathrm{Nb}, \mathrm{La}, \mathrm{Ce}$, $\mathrm{Zr}, \mathrm{Y}$ and $\mathrm{Zn}$ relative to scoria clasts.

Texturally, the pumice clasts have a glassy groundmass, with well-developed vesicles on a scale of $10 \mathrm{~s}$ to $100 \mathrm{~s}$ of $\mu \mathrm{m}$ (Figure $5 \mathrm{~A}$ ). Crystallinity is $\sim 10 \%$ with common phases $(<2 \mathrm{~mm})$ being alkali feldspar, quartz, clinopyroxene and fayalitic olivine (in decreasing order of abundance). Minor FeTi-oxides and zircon are present as inclusions within minerals. All mineral phases are euhedral, with no evidence of resorption (see Supplementary Material). Scoria clasts are phenocryst poor $(<5 \%$ crystals $)$ with a microcrystalline groundmass composed of feldspar, clinopyroxene and Fe-Ti-oxides. Scoria clasts have larger vesicles than the pumice (mm-scale). Distinct inclusions of felsic glass occur in the scoria glass shards, with contacts be-

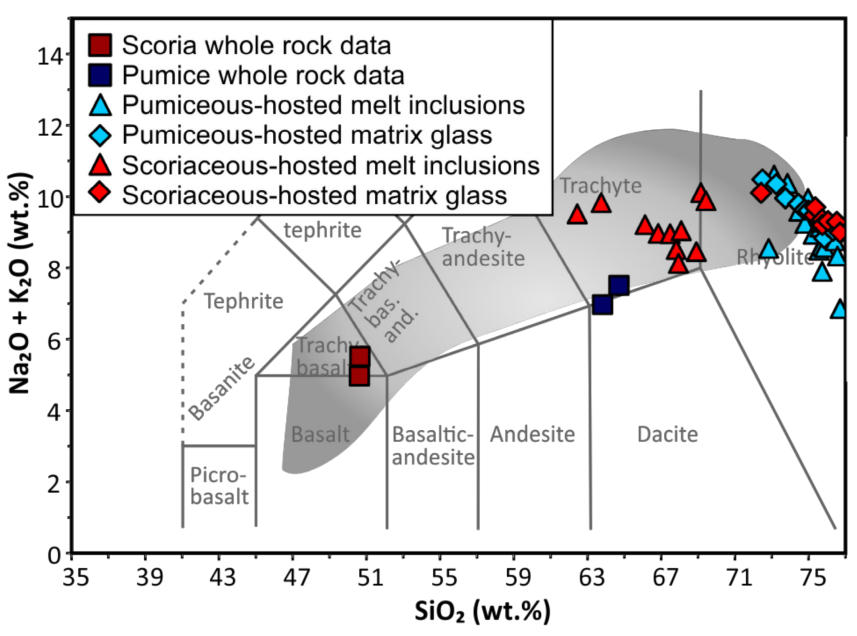

Figure 4: Total alkalis-silica plot [after Le Bas et al. 1992]. Grey field represents previously collected Ascension Island whole rock compositions from Weaver et al. [1996], Jicha et al. [2013] and Chamberlain et al. [2019]. XRF whole rock analyses as squares, EPMA matrix glass as diamonds, and EPMA melt inclusions as triangles.

tween the two textural components retaining their interfingered characteristics (Figure 5B, 5C). Phenocrysts, here used to refer to minerals larger than the groundmass, and with no adhering felsic glass, are feldspar and clinopyroxene with minor forsteritic olivine and FeTi-oxides. Felsic glass-coated quartz, fayalitic olivine and ternary feldspars are also present, with contacts between mineral, felsic glass and mafic glass visible in BSE imagery (Figure 5D). All minerals retain a euhedral appearance, irrespective of the composition of the glass selvedge on the mineral face. Intermediate composition ternary feldspars have faint complex zoning.

\subsection{Crystal cargo compositions}

Feldspars in the pumice clasts are anorthoclase $\left(\sim \mathrm{An}_{<1} \mathrm{Ab}_{63} \mathrm{Or}_{37}\right)$ in composition with relatively restricted ranges. There is no significant difference in major or trace element compositions between mineral cores and rims, and zoning was not observed in BSE images (Figure 6A). Feldspars in the scoria clasts have a much larger range in composition, from anorthoclase $\mathrm{An}_{<1} \mathrm{Ab}_{63} \mathrm{Or}_{37}$ to labradoritic $\sim \mathrm{An}_{62} \mathrm{Ab}_{37} \mathrm{Or}_{1}$ (Figure 6A), but still show no systematic difference between core and rim compositions, and no systematic zoning. Trace element concentrations of $\mathrm{Ti}, \mathrm{Zn}, \mathrm{Sr}, \mathrm{Ba}$, $\mathrm{Eu}, \mathrm{Pb}$ are lower and restricted in the pumice-hosted feldspars, and variable to higher concentrations in the scoria-hosted feldspars (see Supplementary Material).

Clinopyroxene is the dominant mafic mineral phase in the mingled fall deposit: in pumice clasts this is $\mathrm{Na}$ rich with higher concentrations of Sc, Zn, Sr, Zr, Y and all REE, whereas in scoria samples these are more Na- 

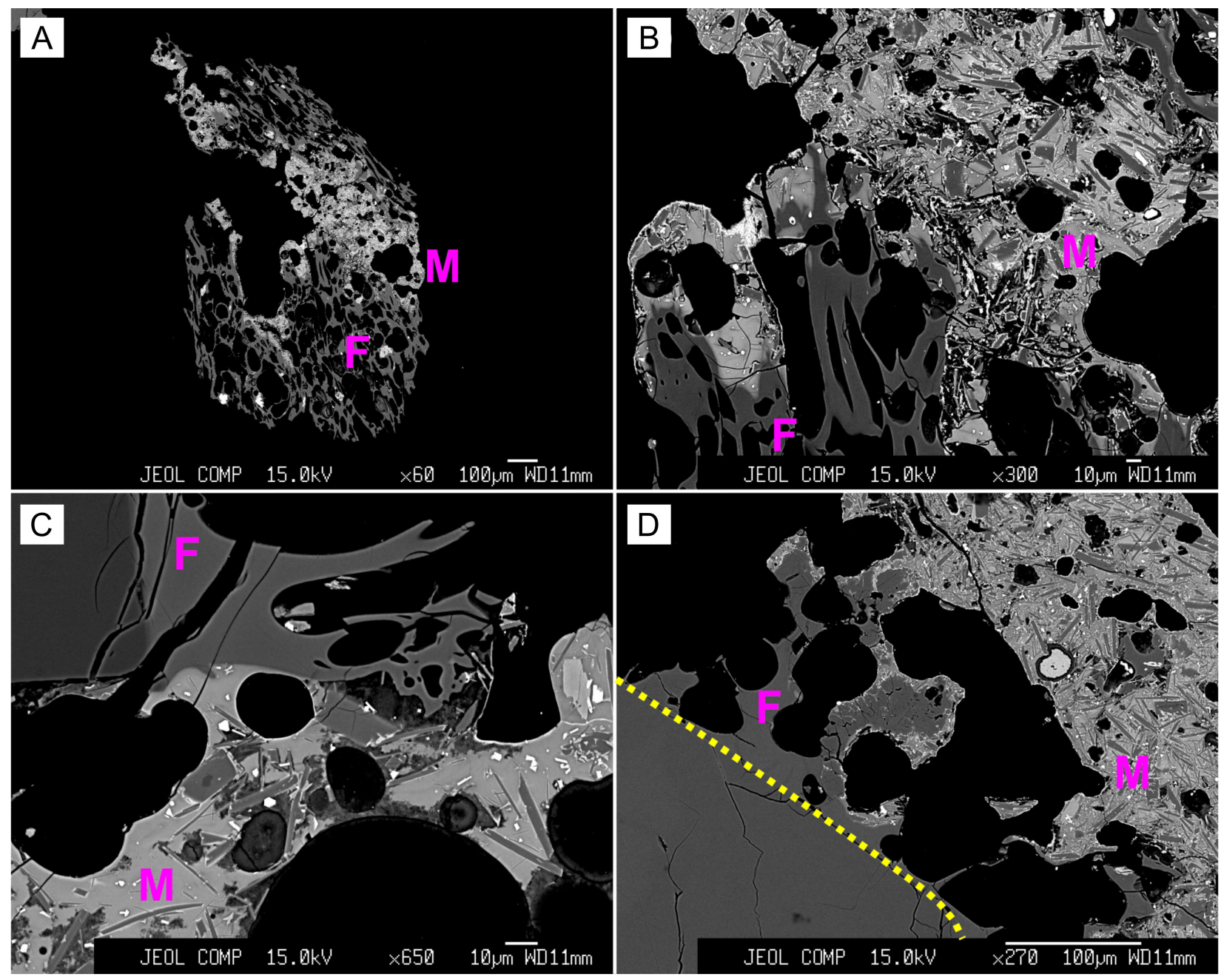

Figure 5: Representative BSE images of mineral and glass textures from the mingled fall deposit. [A] Mixed clast showing the contact between the darker grey, vesicular felsic glass (F) and the microcrystalline mafic glass (M), scale bar is $100 \mu \mathrm{m}$ in length; [B, C] Contact between felsic glass (F) and mafic microcrystalline glass (M) preserving fine scale structures along the interface of the two different glasses, scale bar is $10 \mu \mathrm{m}$ in length; [D] 'mafic' feldspar mineral from the scoria material showing a felsic glass selvedge $(\mathrm{F})$ in contact with the microcrystalline mafic glass (M), scale bar is $100 \mu \mathrm{m}$ in length. Contact between feldspar and felsic glass shown by dashed line.

poor (Figure 6B) with higher concentrations of Ti and Co (Electronic Appendix). Fayalitic (Fa96-97) olivine is present in the pumice clasts, whereas forsteritic olivine (Fa47-54) are identified in scoria clasts. None of the mafic phases exhibit variations between core and rim compositions (Figure 6B, Supplementary Material).

\subsection{Glass compositions}

Matrix glass compositions, determined by EPMA, from bulk pumice sample of L2B are rhyolitic with between 72.5 and 77.4 wt. $\% \mathrm{SiO}_{2}$ (Figure 4). Clinopyroxeneand fayalite-hosted melt inclusions from the pumice sample are rhyolitic and indistinguishable in composition from the matrix glass in terms of major elements (Figure 4). Analyses of the scoria glass were not possible due to its microcrystalline nature. Microlite-free glass selvedges of minerals hosted in the scoria are all rhyolitic and represent the physical mingling of both minerals and glass into the scoria material (see Figure 5D). Melt inclusion compositions from clinopyroxene and FeTi oxides found within the scoria bulk sample of unit L3 are less-evolved than the pumice melt inclusions, yet still evolved when compared with their host whole rock composition (Figure 4), with $\mathrm{SiO}_{2}$ between 62.5 and 69.5 wt. \%. The minerals hosting these melt inclusions lack a clear scoria glass selvedge, and are instead surrounded by vesiculated and glassy selvedges, that appear more akin to the pumice glass. These melt inclusion analyses are therefore not considered representative of the mafic glass end-member, rather a third (trachytic) melt. When trace elements are considered, higher silica glasses (both matrix and melt inclusion glass) have higher concentrations of $\mathrm{Zr}$ and $\mathrm{Rb}$ and lower concentrations of $\mathrm{Ti}, \mathrm{Sr}$ and $\mathrm{Ba}$ (Figure $7 \mathrm{~A}, 7 \mathrm{C}$ ) than in the lower silica glasses. 

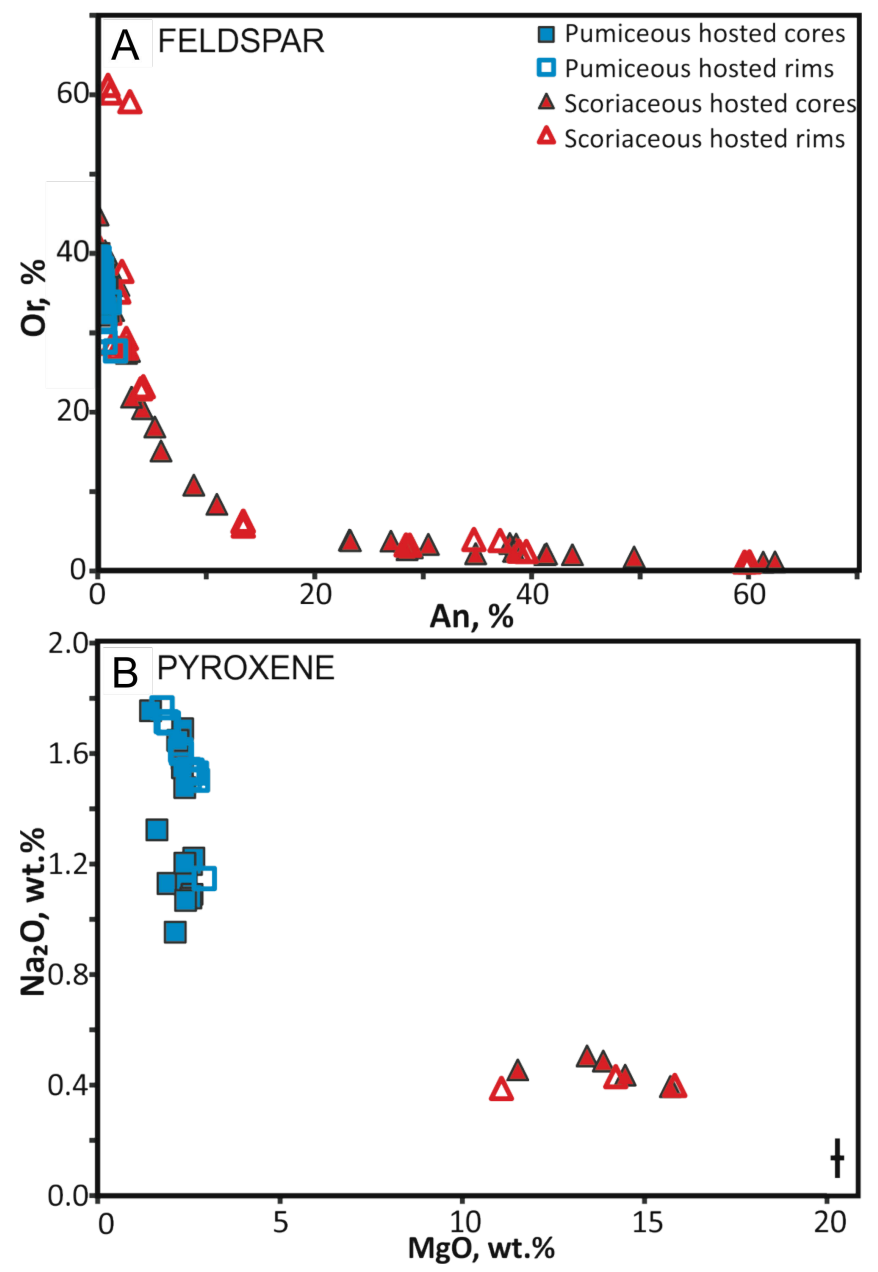

Figure 6: Selected major and trace element data from feldspars [A] and clinopyroxenes [B]. Core analyses are filled symbols, rim analyses are open symbols. Crystals from pumice clasts are in blue, minerals from scoria clasts are in red. Black cross shows the 2 sigma uncertainty on analyses [B], uncertainty on feldspar analyses is less than the size of the symbol used.

Volatile concentrations in all melt inclusions from the pumice and scoria samples yield $\mathrm{H}_{2} \mathrm{O}$ concentrations between 2.13 and 8.28 wt. \%, and $\mathrm{CO}_{2}$ between the detectable limit and $870 \mathrm{ppm}$. (Figure 7E). Scoriahosted melt inclusions have $\mathrm{H}_{2} \mathrm{O}$ concentrations between 2.13 and 6.04 wt. \% and $\mathrm{CO}_{2}$ between 263 and 830 ppm. Pumice-hosted melt inclusions have $\mathrm{H}_{2} \mathrm{O}$ concentrations between 3.89 and 8.28 wt. \% and $\mathrm{CO}_{2}$ between 21 and $870 \mathrm{ppm}$. Water and carbon dioxide concentrations are not coupled with trace element variations, and thus are interpreted to represent varying degrees of volatile loss. Melt inclusions are only observed in a $2 \mathrm{D}$ plane, and their connectedness to the crystal rim could not be assessed. Fluorine concentrations vary between 1300 and 4770 ppm, chlorine concentrations range between 2590 and 4940 ppm (Figure $7 \mathrm{~B}$ ), with higher $\mathrm{F}$ and $\mathrm{Cl}$ concentrations in the trachytic glass (only found as melt inclusions). Both $\mathrm{F}$ and $\mathrm{Cl}$ show positive correlations with $\mathrm{Zr}, \mathrm{Rb}$ and $\mathrm{Nb}$
(Figure 7D). To account for post entrapment crystallisation (PEC) melt inclusions and host minerals were tested for equilibrium using the formula of Putirka [2008]. Where $\mathrm{Kd}_{\text {cpx-liq }}$ Fe-Mg fell outside of the specified $0.28 \pm 0.08$ value, proportions of the host mineral were added until this range was achieved. For all inclusions where major element analyses were available for both inclusion and host mineral this represented $\leqslant 3 \%$ PEC, supported by the absence of shrinkage bubbles in the melt inclusions. To account for the impact of PEC on volatile concentrations, revised concentrations have been calculated by adding the composition of the (anhydrous) host mineral to the melt inclusion. For those inclusions where major element data were not obtained an average uncertainty of $\pm 0.1 \mathrm{wt} \% \mathrm{H}_{2} \mathrm{O}$ and $\pm 5 \mathrm{ppm}$ $\mathrm{CO}_{2}$ can be assumed with potential PEC.

\section{Magmatic Variables}

Many minerals are not in apparent equilibrium with the whole rock or matrix glass compositions they have been erupted with, limiting the applicability of thermobarometry. Limited coexisting Fe-Ti oxide pairs in equilibrium (following the test of Bacon and Hirschmann [1988]) were found. These came from minerals found in the mafic-dominant material, and yielded temperatures between $860{ }^{\circ} \mathrm{C}$ and $930{ }^{\circ} \mathrm{C}$, with $f \mathrm{O}_{2}$ of -0.75 and $+0.2 \log$ units relative to the Nickel-Nickel Oxide (NNO) buffer, using the calibration of Ghiorso and Evans [2008]. This is comparable with the oxygen fugacities obtained for other eruptions from Ascension Island [Chamberlain et al. 2019].

In order to use melt inclusion volatile concentrations to yield entrapment pressures, a temperature must be assumed. Based on our Fe-Ti oxide thermometry and the thermometry of Chamberlain et al. [2019] we use $900^{\circ} \mathrm{C}$ for the melt inclusions hosted in minerals found within the scoria material, and $800{ }^{\circ} \mathrm{C}$ for pumice material (where no equilibrium oxides were found, based on data from other Ascension Island samples [Chamberlain et al. 2019]). Whilst entrapment pressures are affected by temperatures, a change in $50{ }^{\circ} \mathrm{C}$ results in $\sim 15 \mathrm{MPa}$ difference, equivalent to a depth uncertainty of $0.5 \mathrm{~km}$. Entrapment pressures were calculated using the MagmaSat application developed from Ghiorso and Gualda [2015] that utilises both volatile concentrations and major element composition of the melt inclusion. Given the potential for connectivity between a 'trapped' inclusion and the mineral face in the third dimension, the maximum modelled entrapment pressures are considered to reflect true entrapment pressures. For both the scoria- and pumice-hosted melt inclusions this is modelled to be $330 \mathrm{MPa}$ (Figure 7F). This pressure corresponds to a depth of $\sim 11 \mathrm{~km}$. This depth-within the lowermost oceanic crust-is $1 \mathrm{~km}$ above the identified seismic Moho at $12 \mathrm{~km}$ [Klingelhöfer et al. 2001]. 

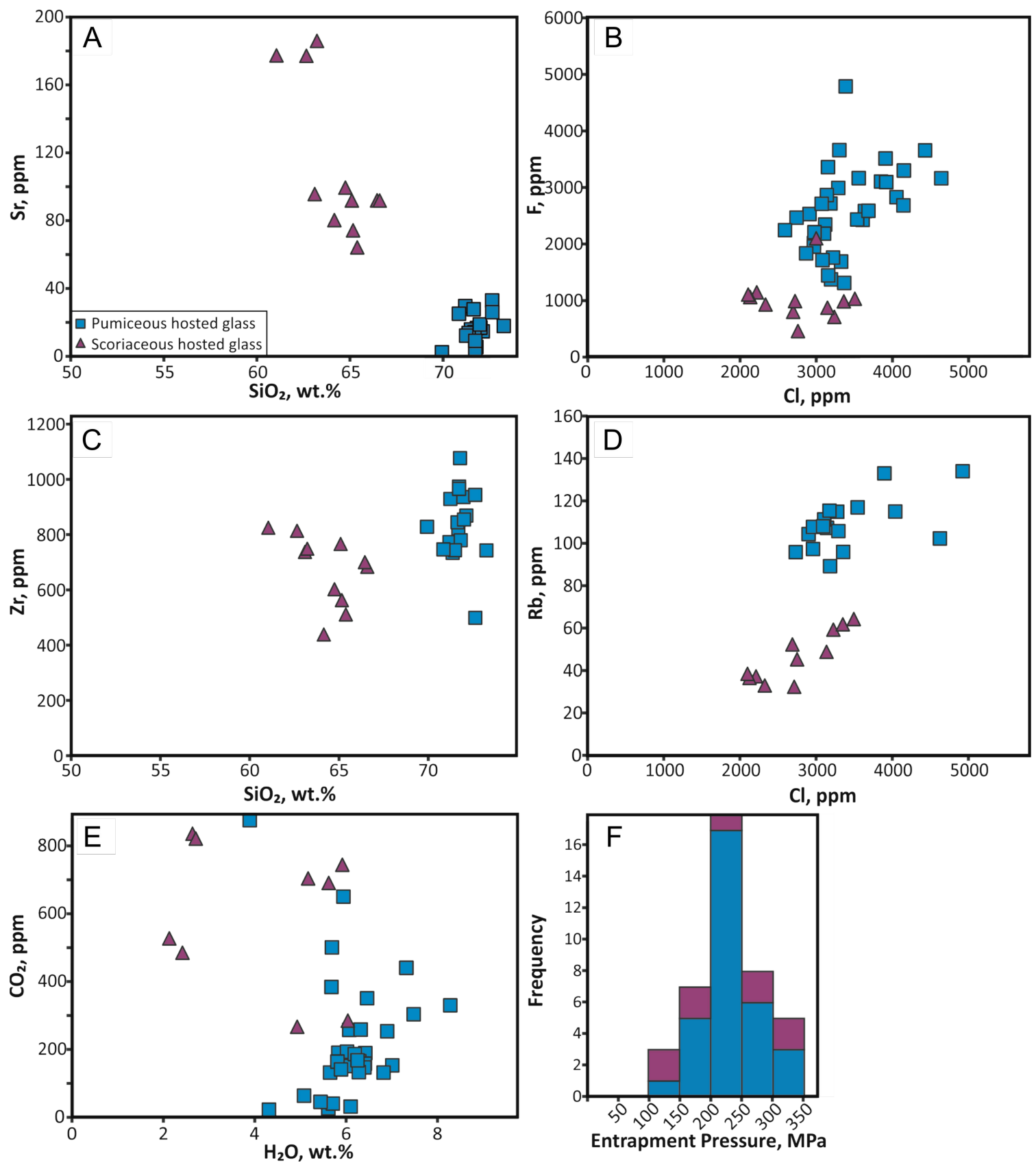

Figure 7: $[\mathrm{A}]-[\mathrm{E}]$ Compositional variation in major, trace and volatile elements in melt inclusions from the mingled fall deposit; [F] Histogram of modelled entrapment pressures in MPa from all melt inclusions, modelled using the MagmaSat application of Ghiorso and Gualda [2015].

\section{Discussion}

\subsection{Generation of heterogeneous melts}

Previous studies have examined the origin of the mafic magmas at Ascension (see Paulick et al. [2010] for isotopic data regarding the formation of Ascension Island separate to Mid Atlantic Ridge volcanism), and how these mafic magmas differentiate into more felsiccompositions via closed-system fractional crystallisation [e.g. Chamberlain et al. 2019; Jicha et al. 2013; Kar et al. 1998]. However, the mingled fall deposit demon- strates that multiple melt batches can be erupted synchronously at Ascension, characteristic of open-system behaviour. In light of the new evidence from the mingled fall deposit, we use the glass and mineral data to re-examine the possible influence of open-system processes on the genesis of heterogeneous melt batches at Ascension. Major and trace element glass compositions define two clear compositional groups (Figures 4 and 7A), which are rhyolitic and trachytic (Figure 7). Neither of these melts is characteristic of the microcrystalline mafic melt, which could not be geochemically finger-printed here (Figure 5B). Interestingly the 
mineral cargo of the scoria end-member shows a range in compositions (Figure 6A), indicative of multiple sources of the phenocrysts erupted in the more mafic component. Using the equilibrium model of Panjasawatwong et al. [1995] for plagioclase feldspars, only the labradoritic feldspars are in equilibrium with the trachy-basaltic whole rock composition (hand-picked to minimise degree of mingling present in the sample). Similarly, only the high $\mathrm{Mg \#} \mathrm{(>55)} \mathrm{clinopyroxenes}$ are in $\mathrm{Fe}-\mathrm{Mg}$ equilibrium with the trachy-basalt (using the method of Smith et al. [2010]). All other (moreevolved) mineral phases found within the scoria clasts are inferred to be late-stage mechanically incorporated minerals (due to the lack of a well-developed overgrowth rim: Figure 6), some of which retain their host melt selvedge (Figure 5D). Less mineral incorporation has apparently occurred within the felsic clasts, likely due to its higher viscosity, with the quartz, anorthoclase feldspar, fayalite (Mg\#2-4) and low Mg\# (<15) clinopyroxene being in equilibrium with their erupted glass compositions (Figure 6; using the method of Smith et al. [2010]). The accumulation of ante- or xenocrysts within the melt is further evidenced by the presence of cognate but magma-coated plutonic enclaves within the deposit (Figure 3C), which are more dominant in the later, scoria subunit L3 (Figure 2).

Given the previously published evidence for the importance of extensive crystallisation producing the evolved melts at Ascension Island [e.g. Chamberlain et al. 2019; Jicha et al. 2013] we first test the possibility that the rhyolitic end-member composition measured in glass selvedges and melt inclusions (Figure 4) was produced by simple closed-system isobaric equilibrium crystallisation. The Rhyolite-MELTS model of Gualda and Ghiorso [2015] was applied using a starting composition of the mafic end-member from Chamberlain et al. [2019] and a pressure of $330 \mathrm{MPa}$ based on our melt inclusion maximum entrapment pressures (Figure 7). Modelling results show that even extensive crystallisation at $330 \mathrm{MPa}$ cannot reproduce the rhyolitic compositions trapped in the minerals (pressures less than 250 MPa are apparently required to evolve to rhyolitic compositions, Chamberlain et al. [2019]). Instead we consider an alternative method for producing the rhyolitic melt.

Many authors have invoked partial melting of lowercrustal material to produce felsic melts [e.g. Angelo 2013; Hildreth 1981; Kimura 2002; Sigurdsson 1977]. The high entrapment pressure of melt inclusions that are known to have formed within rhyolite melt due to their rhyolitic selvedges, suggest that melting of lower crustal cumulates could be a source of the rhyolite. Accordingly we performed trace element batch partial melting following the method of Shaw [1970] using various mineralogies of Ascension plutonic gabbros as described by Harris [1983]. However available data does not account for minor phases (not quantified in the work of by Harris [1983]). Subsequently, none of the proposed starting points can well reproduce key trace element ratios of the rhyolite, with the closest values being obtained by moderate degrees of partial melting of olivine-rich gabbros $(\sim 10 \%)$. Further work using radiogenic and oxygen isotopes [c.f. Gurenko et al. 2015] would allow a more reliable test of the role of partial melting in producing the rhyolites, but MELTS modelling [Chamberlain et al. 2019] has revealed that closed-system fractionation alone cannot produce the water-rich rhyolite melt; therefore we view partial melting of gabbroic cumulates as the most likely process of generating the rhyolite melt observed in the mingled fall deposit.

Ocean island volcanoes are generally built on thinner and more dense crust than most subduction volcanoes, yet our identification of a lower crustal hot-zone [c.f. Annen et al. 2006] with evolved melts at depths close to the Moho (Figure 7F) suggests that many similarities can exist across tectonic settings [e.g. Guo et al. 2007; Humphreys et al. 2006b; Johnson et al. 2008]. Ascension Island is a low-flux ocean island [Minshull et al. 2010] and would appear to be a less-likely candidate for lower-crustal melting due to its lower input rates of lower-crustal basalt [Annen et al. 2006]. Yet whilst the production of evolved melts at Ascension Island is dominated by fractional crystallisation [Chamberlain et al. 2019; Jicha et al. 2013], the recognition of partial melting in the lower crust to generate water-rich rhyolite in the mingled fall deposit highlights the diversity in felsic melt generation processes, even at a nested and mainly closed-system magmatic plumbing systems [Chamberlain et al. 2019], which include those more associated with higher-flux ocean island volcanoes [e.g. Bohrson and Reid 1998; Lacasse et al. 2007; Sigurdsson 1977].

\subsection{Timing of mingling event}

Key to understanding future unrest timescales at active volcanic centres such as Ascension Island [c.f. Preece et al. 2018] is the quantification of timescales of magmatic processes occurring prior to eruption. Processes identified in previous volcanic eruptions could then provide crucial context when monitoring future periods of volcanic unrest. The timing of magma mingling prior to eruption of the mingled fall deposit can be elucidated from zoning (or lack of) within minerals [e.g. Chamberlain et al. 2014; Morgan et al. 2004], and the structures preserved in mafic-felsic glass contacts [e.g. Montagna et al. 2015; Perugini et al. 2015; Perugini et al. 2010]. Mineral phases lack clear overgrowth patterns that would be expected if magma mingling occurred within weeks to days of eruption (Figure 5, c.f. Hartley et al. [2016]; Singer et al. [2016]; Petrone et al. [2018]). Therefore, either mingling of magmas has occurred significantly long enough prior to eruption for chemical diffusion to equilibrate across entire mineral grains or so shortly prior to eruption that it is not recorded in 
the mineral phases. Glass contacts between mafic and felsic glass preserves clear magma mingling structures (Figure 5) on a micron scale. Whilst no direct experimental constraints exist for the compositional contrast observed in this deposit, experiments on alkaline melts similar to the evolved compositions present at Ascension suggest that the glass textures observed in mingled fall deposit could reflect timescales of magma mingling on the order of hours to days before eruption [Perugini et al. 2010]. Given the similarity between the structure preserved in clasts in the mingled fall deposit and the numerical simulation of magma mingling of Montagna et al. [2015] we suggest that a timescale on the order of hours is most appropriate in this case. Using our modelled entrapment depth of $11 \mathrm{~km}$, this gives average ascent rates on the order of $0.13 \mathrm{~ms}^{-1}$ (for mingling timescales of 24 hours prior to eruption) comparable with estimates for ascent rate for vulcanian eruptions from Sakurajima [Miwa et al. 2009]. The potentially short timescales of magma mingling prior to ascent suggest that further work is needed to understand viscosity constraints on magma mingling in these compositions of alkaline melts that contain high concentrations of volatiles. The timescales of this mingling process suggest that there may be little warning prior to a similar eruption in the future.

\subsection{Eruption mechanisms of the mingled fall deposit}

The scarcity of outcrops of the mingled fall deposit on the island (Figure 1) precludes the construction of isopleth or isopach maps, and thus neither the eruptive volumes nor vent location can be constrained. However, based on the observations detailed above (Section 3) some inferences about the sequence of eruptive activity can be drawn. Phase 1 of the eruption, represented by the ash of subunit A began with the explosive, yet spatially constrained eruption of felsic magmas (based on their light colour) and deposition of ultrafine, well-sorted ashy fall deposit, lacking any internal stratification. The contact between subunit $\mathrm{A}$ and subunit L1 is mildly undulatory (on a $5 \mathrm{~cm}$ amplitude) a result of variable thickness of the phase 1 deposits. The nature of this contact suggests a time break on the order of days to weeks before the deposition of subunit L1 to allow wind erosion to occur. Crucially, weathering was not observed, and vegetation traces were not found in subunit A therefore a time break on the order of weeks can be considered a maximum time break. Phase 2, typified by the dense scoria subunit L1 with two coarsening upwards beds, contains sparse juvenile material, and is not present in every locality where the mingled fall deposit is identified. This phase could represent phreatic or phreatomagmatic eruptions clearing the vent, prior to the main magmatic phase of the eruption. Given the limited spatial extent of subunit L1, this is likely represents two phases of eruptive activity. The magmatic phase of the eruption begins with Phase 3, represented by subunits L2A and L 2B both of which are fall deposits from established eruption columns with their moderately-well-sorted nature and angular clasts. Subunits L2 and L3 are found in all localities that the mingled fall has been identified, representing the establishment of a sustained eruption column that may have been of subplinian proportions. Variation in juvenile material characteristics within subunit L2 is interpreted to represent varying vesiculation of the mingled magma (which is dominantly felsic). Upwards coarsening could have resulted from waxing of the column or from changes in wind direction. The presence of outsized (i.e. coarser than pumice material) lithic clasts within unit L 2 highlights the proximity to vent, as these clasts must represent ballistic ejecta, rather than classic fall. Phase 4 , the final phase of eruption is typified by the change in composition, rather than eruption column dynamics, from a dominantly felsic to a dominantly mafic magma being erupted. The transition from L 2 to L 3 is sharp and reflects the stratification of magmas that was maintained on a large scale (with fine scale mingling of individual glass batches).

\subsection{Implications for future volcanic activity at Ascen- sion Island}

The mingled fall deposit, is a key marker unit within Ascension Island stratigraphy, and would have covered a large part of island in tephra, yet preservation and exposure has limited the localities it is observed within the field (Figure 1). The presence of oversize plutonic lithic clasts in every location highlights that deposits are all found within the ballistic ejecta zone, the extent of which would be controlled by many factors such as elevation of the vent structure [Nurmawati and Konstantinou 2018] which is as yet unidentified. The probable-subplinian deposit shows no evidence for a time break during eruption (Figure 2) thus the eruption would be relatively short-lived. However, as evidenced by the well-sorted coarse fall deposit (Figure 2) that characterises the majority of the deposit it is likely to have produced a sustained eruption column that would significantly affect air travel to and from the island if a similar event occurred in the future.

Melt inclusion entrapment pressures suggest deep production and stalling (to allow the formation of the melt inclusions within crystal phases) of the magmas that fed the mingled fall deposit. The combination of deep accumulation of melt with relatively small eruptive volumes suggests that traditional monitoring techniques commonly used to infer accumulation of eruptive magma [e.g. Biggs and Pritchard 2017; Magee et al. 2018; Sparks et al. 2012] will be unable to resolve a similar low-volume accumulation of eruptible melt at depth at Ascension. Use of multiple seismometers may be able to trace deep pulses of magmatism [c.f. Bagnardi and Amelung 2012; Lengliné et al. 2016] that may trigger partial melting of gabbroic material or mixing 
with rhyolitic melt already present at depth. The challenge will come in anticipating if increased seismicity is related to magmatic intrusion, or an eruption triggering event.

Measured water concentrations are very high in the rhyolitic melt inclusions (up to $8 \mathrm{wt} . \% \mathrm{H}_{2} \mathrm{O}$ ) and decrease melt viscosity [Giordano et al. 2004], a key control of magma ascent rate [e.g. Caricchi et al. 2016; Papale et al. 1998], as well as providing a strong buoyancy aid as ongoing volatile exsolution leads to bubble growth. These melt inclusions reflect the highest measured magmatic water concentrations for any Ascension Island felsic magmas from melt inclusion analysis [Chamberlain et al. 2016], yet prior alkali feldsparmelt hygrometry [Chamberlain et al. 2019; Mollo et al. 2015] suggest high (4.6-8.1 wt. \%) water concentrations of felsic Ascension Island magmas. Mingling of two distinct magmas at contrasting temperatures has been suggested to trigger bubble nucleation [ParedesMariño et al. 2017] due to the reduced solubility of water in felsic melts at higher temperatures. Thus, pre-existing high water concentrations within the felsic melts, combined with interaction with a hotter, more mafic melt, will trigger rapid volatile exsolution and provide an effective trigger for explosive eruptions at Ascension Island. Should other mafic magmas encounter water-saturated felsic melts within the nested magmatic plumbing system [Chamberlain et al. 2019] a similarly explosive eruption could occur.

\section{Conclusions}

We present field observations and geochemical data on a newly-identified mingled fall deposit on Ascension Island that highlights the potential for open-system processes at a low magmatic flux ocean island, and reveals similarities with other ocean islands such as Iceland and the Canaries where extensive evidence for magma mixing is preserved in both glass and mineral textures [e.g. Sigmarsson et al. 2011; Sigurdsson and Sparks 1981; Sliwinski et al. 2015; Wiesmaier et al. 2011]. Mineral phases found within the mingled fall deposit are from heterogeneous sources, with many minerals within the scoria end-member apparently being mechanically incorporated during mingling.

Clinopyroxene- and fayalite-hosted melt inclusions have high volatile concentrations (up to 8 wt. $\% \mathrm{H}_{2} \mathrm{O}$ ) reflective of entrapment at the lower-most oceanic crust at approximately $11 \mathrm{~km}$ depth. These melt inclusions are rhyolitic and reflect deep generation of evolved melts through partial melting of olivine-rich gabbroic lithologies. This generation of felsic melt erupted with the mingled fall deposit through partial melting is juxtaposed with previous work which highlights the importance of extensive crystallisation in generating the majority of the felsic melts at Ascension Island [Chamberlain et al. 2019; Jicha et al. 2013; Kar et al. 1998].
Therefore, detailed study of multiple deposits is key to unravel the complex and varied processes responsible for melt evolution in small ocean island volcanoes, such as Ascension Island.

Whilst the rhyolitic melt is water-rich, the eruption of the mingled fall deposit was triggered by mingling with a crystal-poor mafic melt. The mingling likely occurred within 24 hours of eruption, as demonstrated by the lack of zoning within mineral phases, and the complex nature of mafic and felsic glass contacts. With the nearest landmass of St Helena being $>1,200 \mathrm{~km}$ away, the short timescales between magma mingling and eruption emphasises the importance of anticipating future eruptive activity at Ascension Island. The deep storage of the mingled fall deposit rhyolite coupled with the small-volume of felsic magma raises significant challenges for forecasting similar activity at Ascension Island in the future, and further work to deduce ascent rates of other erupted magmas should be undertaken to better quantify risk to the resident population of Ascension.

\section{ACKnOWledgements}

In memory of Jon Davidson, who inspired so many. The authors wish to thank the Ascension Island Government, the Ascension Island Heritage Society, Ascension Island Conservation Department and Ascension Island residents (in particular Drew Avery) for logistical support during field campaigns. Thoughtful reviews by Brian Jicha and Charlotte Gordon, discussion with Jane Scarrow and Bridie Davies, and expedient editorial handling by Sami Mikhail have all enriched this publication. The authors are grateful to Chris Hayward, Ian Schipper, Richard Hinton, John Craven, Cees-Jan de Hoog, Bertrand Lezé, Chris Ottley and George Cooper for their laboratory and technical assistance during the course of analyses for this project. This project was funded by a Leverhulme Trust Research Project Grant (RPG-2013-042), with a field season supported by a Gloyne Outdoor Geological Research award from the Geological Society of London. Ion microprobe time was funded by the Natural Environment Research Council Grant (IMF561/0515).

\section{Author contributions}

Katy Chamberlain, Richard Brown and Katie Preece collected and interpreted field data regarding the deposit; Katy Chamberlain and Jenni Barclay collected SIMS data; Katy Chamberlain and Iona McIntosh discussed volatile data; Katy Chamberlain collected all other geochemical data. All authors contributed to the writing of the paper. 


\section{Data AVAilability}

Electronic Appendices, as well as the accepted version of the submission will be available through the UDORA open access research archive: https:// derby.openrepository.com/. Supplementary material is available alongside the online version of this article.

\section{Copyright NOTICE}

(C) The Author(s) 2020. This article is distributed under the terms of the Creative Commons Attribution 4.0 International License, which permits unrestricted use, distribution, and reproduction in any medium, provided you give appropriate credit to the original author(s) and the source, provide a link to the Creative Commons license, and indicate if changes were made.

\section{REFERENCES}

Ablay, G. J., M. R. Carroll, M. R. Palmer, J. Marti, and R. S. J. Sparks (1998). "Basanite-Phonolite Lineages of the Teide-Pico Viejo Volcanic Complex, Tenerife, Canary Islands". Journal of Petrology 39.5, pp. 905936. Dor: $10.1093 /$ petroj/39.5.905.

Angelo, P. (2013). "Petrogenesis of trachyte and rhyolite magmas on Ponza Island (Italy) and its relationship to the Campanian magmatism". Journal of Volcanology and Geothermal Research 267, pp. 15-29. Dor: 10.1016/j. jvolgeores.2013.09.008.

Annen, C., J. D. Blundy, and R. S. J. Sparks (2006). "The Genesis of Intermediate and Silicic Magmas in Deep Crustal Hot Zones". Journal of Petrology 47.3, pp. 505-539. DoI: 10.1093/petrology/egi084.

Bacon, C. R. and M. M. Hirschmann (1988). "Mg/Mn partitioning as a test for equilibrium between coexisting Fe-Ti oxides". American Mineralogist 73.1-2, pp. 57-61.

Bagnardi, M. and F. Amelung (2012). "Space-geodetic evidence for multiple magma reservoirs and subvolcanic lateral intrusions at Fernandina Volcano, Galápagos Islands". Journal of Geophysical Research: Solid Earth 117.B10. Dor: 10.1029/2012jb009465.

Biggs, J. and M. E. Pritchard (2017). "Global Volcano Monitoring: What Does It Mean When Volcanoes Deform?" Elements 13.1, pp. 17-22. Dor: 10.2113/ gselements.13.1.17.

Bohrson, W. A. and M. R. Reid (1998). "Genesis of Evolved Ocean Island Magmas by Deep- and Shallow-Level Basement Recycling, Socorro Island, Mexico: Constraints from Th and other Isotope Signatures". Journal of Petrology 39.5, pp. 995-1008. DoI: 10.1093/petroj/39.5.995.

Bohrson, W. A. and M. R. Reid (1995). "Petrogenesis of alkaline basalts from Socorro Island, Mexico: Trace element evidence for contamination of ocean island basalt in the shallow ocean crust". Journal of Geophys- ical Research: Solid Earth 100.B12, pp. 24555-24576. DOI: $10.1029 / 95$ jb01483.

Brenna, M., S. Nakada, D. Miura, K. Toshida, H. Ito, N. Hokanishi, and S. Nakai (2015). "A trachyte-syenite core within a basaltic nest: filtering of primitive injections by a multi-stage magma plumbing system (Oki-Dōzen, south-west Japan)". Contributions to Mineralogy and Petrology 170.2. Dor: 10.1007/s00410$015-1181-0$.

Brooker, R., S. Kohn, J. Holloway, P. McMillan, and M. Carroll (1999). "Solubility, speciation and dissolution mechanisms for $\mathrm{CO} 2$ in melts on the NaAlO2-SiO2 join". Geochimica et Cosmochimica Acta 63.21, pp. 3549-3565. DoI: 10.1016/s0016-7037 (99) 00196-9.

Caricchi, L., G. Simpson, and U. Schaltegger (2016). "Estimates of Volume and Magma Input in Crustal Magmatic Systems from Zircon Geochronology: The Effect of Modeling Assumptions and System Variables". Frontiers in Earth Science 4. Dor: 10 . 3389/ feart.2016.00048.

Carley, T. L., C. F. Miller, J. L. Wooden, I. N. Bindeman, and A. P. Barth (2011). "Zircon from historic eruptions in Iceland: reconstructing storage and evolution of silicic magmas". Mineralogy and Petrology 102.1-4, pp. 135-161. DOI: 10.1007/s00710-011-0169-3.

Carmichael, I. S. E. (1964). "The Petrology of Thingmuli, a Tertiary Volcano in Eastern Iceland". Journal of Petrology 5.3, pp. 435-460. Dor: $10.1093 /$ petrology/5.3.435.

Carracedo, J., E. R. Badiola, H. Guillou, M. Paterne, S. Scaillet, F. P. Torrado, R. Paris, U. Fra-Paleo, and A. Hansen (2007). "Eruptive and structural history of Teide Volcano and rift zones of Tenerife, Canary Islands". Geological Society of America Bulletin 119.910, pp. 1027-1051. Dor: 10.1130/b26087.1.

Chamberlain, K. J., J. Barclay, K. J. Preece, R. J. Brown, and J. P. Davidson (2019). "Lower Crustal Heterogeneity and Fractional Crystallization Control Evolution of Small-volume Magma Batches at Ocean Island Volcanoes (Ascension Island, South Atlantic)". Journal of Petrology 60.8, pp. 1489-1522. DoI: 10.1093/ petrology/egze37.

Chamberlain, K., J. Barclay, K. Preece, R. Brown, and J. Davidson (2016). "Origin and evolution of silicic magmas at ocean islands: Perspectives from a zoned fall deposit on Ascension Island, South Atlantic". Journal of Volcanology and Geothermal Research 327, pp. 349-360. DoI: 10.1016/j . jvolgeores. 2016.08. 014.

Chamberlain, K. J., D. J. Morgan, and C. J. N. Wilson (2014). "Timescales of mixing and mobilisation in the Bishop Tuff magma body: perspectives from diffusion chronometry". Contributions to Mineralogy and Petrology 168.1. Dor: 10.1007/s00410-014-1034-2.

Frey, F. A., W. S. Wise, M. O. Garcia, H. West, S.-T. Kwon, and A. Kennedy (1990). "Evolution of Mauna Kea Volcano, Hawaii: Petrologic and geochemical 
constraints on postshield volcanism". Journal of Geophysical Research 95.B2, p. 1271. DOI: 10.1029/ jb095ib02p01271.

Geist, D., K. A. Howard, and P. Larson (1995). "The Generation of Oceanic Rhyolites by Crystal Fractionation: the Basalt-Rhyolite Association at Volc n Alcedo, Gal pagos Archipelago". Journal of Petrology 36.4, pp. 965-982. DoI: $10.1093 /$ petrology/36. 4 . 965.

Geist, D. J., W. M. White, and A. R. McBirney (1988). "Plume-asthenosphere mixing beneath the Galapagos archipelago". Nature 333.6174, pp. 657-660. DoI: $10.1038 / 333657 a 0$.

Ghiorso, M. S. and B. W. Evans (2008). "Thermodynamics of Rhombohedral Oxide Solid Solutions and a Revision of the FE-TI Two-Oxide Geothermometer and Oxygen-Barometer". American Journal of Science 308.9, pp. 957-1039. DOI: 10.2475/09.2008.01.

Ghiorso, M. S. and G. A. R. Gualda (2015). "An $\mathrm{H} 2 \mathrm{O}-\mathrm{CO} 2$ mixed fluid saturation model compatible with rhyolite-MELTS". Contributions to Mineralogy and Petrology 169.6. DoI: $10.1007 /$ s $00410-015-1141-$ 8.

Giordano, D., C. Romano, D. Dingwell, B. Poe, and H. Behrens (2004). "The combined effects of water and fluorine on the viscosity of silicic magmas". Geochimica et Cosmochimica Acta 68.24, pp. 5159-5168. DoI: 10.1016/j.gca.2004.08.012.

Gualda, G. A. R. and M. S. Ghiorso (2015). "MELTS_Excel: A Microsoft Excel-based MELTS interface for research and teaching of magma properties and evolution". Geochemistry, Geophysics, Geosystems 16.1, pp. 315-324. DoI: 10.1002/2014gc005545.

Guo, Z., M. Wilson, and J. Liu (2007). "Post-collisional adakites in south Tibet: Products of partial melting of subduction-modified lower crust". Lithos 96.1-2, pp. 205-224. DoI: 10.1016/j.lithos.2006.09.011.

Gurenko, A. A., I. N. Bindeman, and I. A. Sigurdsson (2015). "To the origin of Icelandic rhyolites: insights from partially melted leucocratic xenoliths". Contributions to Mineralogy and Petrology 169.5. DoI: 10 . 1007/s00410-015-1145-4.

Harpp, K. S. and W. M. White (2001). "Tracing a mantle plume: Isotopic and trace element variations of Galápagos seamounts". Geochemistry, Geophysics, Geosystems 2.6, n/a-n/a. DoI: 10.1029/2000gc000137.

Harris, C. (1983). "The Petrology of Lavas and Associated Plutonic Inclusions of Ascension Island". Journal of Petrology 24.4, pp. 424-470. DOI: 10.1093 / petrology/24.4.424.

Hartley, M. E., D. J. Morgan, J. Maclennan, M. Edmonds, and T. Thordarson (2016). "Tracking timescales of short-term precursors to large basaltic fissure eruptions through Fe-Mg diffusion in olivine". Earth and Planetary Science Letters 439, pp. 58-70. DoI: 10.1016/j.eps1.2016.01.018.

Hildreth, W. (1981). "Gradients in silicic magma chambers: Implications for lithospheric magmatism". Jour- nal of Geophysical Research: Solid Earth 86.B11, pp. 10153-10192. DoI: 10.1029/jb@86ib11p10153.

Humphreys, M. C. S., J. D. Blundy, and R. S. J. Sparks (2006b). "Magma Evolution and Open-System Processes at Shiveluch Volcano: Insights from Phenocryst Zoning". Journal of Petrology 47.12, pp. 23032334. DoI: $10.1093 /$ petrology/egl045.

Humphreys, M. C., S. L. Kearns, and J. D. Blundy (2006a). "SIMS investigation of electron-beam damage to hydrous, rhyolitic glasses: Implications for melt inclusion analysis". American Mineralogist 91.4, pp. 667-679. DoI: 10.2138/am.2006.1936.

Jeffery, A. J. and R. Gertisser (2018). "Peralkaline Felsic Magmatism of the Atlantic Islands". Frontiers in Earth Science 6. DoI: 10.3389/feart.2018.00145.

Jicha, B. R., B. S. Singer, and M. J. Valentine (2013). "40Ar/39Ar Geochronology of Subaerial Ascension Island and a Re-evaluation of the Temporal Progression of Basaltic to Rhyolitic Volcanism". Journal of Petrology 54.12, pp. 2581-2596. Dor: $10.1093 /$ petrology/egt 058 .

Jochum, K. P., U. Nohl, K. Herwig, E. Lammel, B. Stoll, and A. W. Hofmann (2005). "GeoReM: A New Geochemical Database for Reference Materials and Isotopic Standards". Geostandards and Geoanalytical Research 29.3, pp. 333-338. Dor: 10.1111/j.1751-908x. 2005. tb00904.x.

Johnson, E. R., P. J. Wallace, K. V. Cashman, H. D. Granados, and A. J. Kent (2008). "Magmatic volatile contents and degassing-induced crystallization at Volcán Jorullo, Mexico: Implications for melt evolution and the plumbing systems of monogenetic volcanoes". Earth and Planetary Science Letters 269.3-4, pp. 478-487. Dor: 10.1016/j .eps1.2008.03.004.

Kar, A., B. Weaver, J. Davidson, and M. Colucci (1998). "Origin of Differentiated Volcanic and Plutonic Rocks from Ascension Island, South Atlantic Ocean". Journal of Petrology 39.5, pp. 1009-1024. Dor: 10.1093/petroj/39.5.1009.

Kimura, J. (2002). "Origin of Low-K Intermediate Lavas at Nekoma Volcano, NE Honshu Arc, Japan: Geochemical Constraints for Lower-Crustal Melts". Journal of Petrology 43.4, pp. 631-661. Dor: $10.1093 /$ petrology/43.4.631.

Klingelhöfer, F., T. Minshull, D. Blackman, P. Harben, and V. Childers (2001). "Crustal structure of Ascension Island from wide-angle seismic data: implications for the formation of near-ridge volcanic islands". Earth and Planetary Science Letters 190.1-2, pp. 41-56. DoI: 10.1016/s0012-821x(01)00362-4.

Koppers, A. A. P. (2005). "Asynchronous Bends in Pacific Seamount Trails: A Case for Extensional Volcanism?" Science 307.5711, pp. 904-907. Dor: 10.1126/ science. 1107260.

Lacasse, C., H. Sigurdsson, S. N. Carey, H. Jóhannesson, L. E. Thomas, and N. W. Rogers (2007). "Bimodal volcanism at the Katla subglacial caldera, Iceland: insight into the geochemistry and petrogenesis of rhy- 
olitic magmas". Bulletin of Volcanology 69.4, pp. 373399. DoI: $10.1007 / \mathrm{s} 00445-006-0082-5$.

Le Bas, M. J., R. W. Le Maitre, and A. R. Woolley (1992). "The construction of the Total Alkali-Silica chemical classification of volcanic rocks". Mineralogy and Petrology 46.1, pp. 1-22. DoI: 10.1007/bf01160698.

Lengliné, O., Z. Duputel, and V. Ferrazzini (2016). "Uncovering the hidden signature of a magmatic recharge at Piton de la Fournaise volcano using small earthquakes". Geophysical Research Letters 43.9, pp. 4255-4262. DOI: 10.1002/2016gl068383.

Leonard, G., J. Cole, I. Nairn, and S. Self (2002). "Basalt triggering of the c. AD 1305 Kaharoa rhyolite eruption, Tarawera Volcanic Complex, New Zealand". Journal of Volcanology and Geothermal Research 115.34, pp. 461-486. DoI: 10.1016/s0377-0273(01)003262.

MacDonald, G. A. and T. Katsura (1964). "Chemical Composition of Hawaiian Lavas". Journal of Petrology 5.1, pp. 82-133. Dor: 10.1093/petrology/5.1.82.

Macdonald, R., R. S. J. Sparks, H. Sigurdsson, D. P. Mattey, D. W. McGarvie, and R. L. Smith (1987). "The 1875 eruption of Askja volcano, Iceland: combined fractional crystallization and selective contamination in the generation of rhyolitic magma". Mineralogical Magazine 51.360, pp. 183-202. Dor: 10.1180/minmag. 1987.051.360.01.

Magee, C. et al. (2018). "Magma Plumbing Systems: A Geophysical Perspective". Journal of Petrology 59.6, pp. 1217-1251. Dor: 10.1093/petrology/egy064.

Mancini, A., H. B. Mattsson, and O. Bachmann (2015). "Origin of the compositional diversity in the basaltto-dacite series erupted along the Heiðarsporður ridge, NE Iceland". Journal of Volcanology and Geothermal Research 301, pp. 116-127. Dor: 10.1016/ j. jvolgeores. 2015.05.010.

Mangan, M. and T. Sisson (2000). "Delayed, disequilibrium degassing in rhyolite magma: decompression experiments and implications for explosive volcanism". Earth and Planetary Science Letters 183.3-4, pp. 441-455. DoI: $10.1016 / \mathrm{s} 0012-821 \mathrm{x}(00) 00299-5$.

Minshull, T. A., O. Ishizuka, and D. Garcia-Castellanos (2010). "Long-term growth and subsidence of Ascension Island: Constraints on the rheology of young oceanic lithosphere". Geophysical Research Letters 37.23, n/a-n/a. DoI: 10.1029/2010gl045112.

Miwa, T., A. Toramaru, and M. Iguchi (2009). "Correlations of volcanic ash texture with explosion earthquakes from vulcanian eruptions at Sakurajima volcano, Japan". Journal of Volcanology and Geothermal Research 184.3-4, pp. 473-486. DOI: $10.1016 / \mathrm{j}$. jvolgeores. 2009.05.012.

Mollo, S., M. Masotta, F. Forni, O. Bachmann, G. D. Astis, G. Moore, and P. Scarlato (2015). "A Kfeldspar-liquid hygrometer specific to alkaline differentiated magmas". Chemical Geology 392, pp. 18. DoI: $10.1016 / \mathrm{j}$. chemgeo . 2014.11.010.
Montagna, C. P., P. Papale, and A. Longo (2015). "Timescales of mingling in shallow magmatic reservoirs". Geological Society, London, Special Publications 422.1, pp. 131-140. DoI: 10.1144/sp422.6.

Morgan, D., S. Blake, N. Rogers, B. DeVivo, G. Rolandi, R. Macdonald, and C. Hawkesworth (2004). "Time scales of crystal residence and magma chamber volume from modelling of diffusion profiles in phenocrysts: Vesuvius 1944". Earth and Planetary Science Letters 222.3-4, pp. 933-946. Dor: 10.1016/j . epsl. 2004.03.030.

Morgavi, D., I. Arienzo, C. Montagna, D. Perugini, and D. B. Dingwell (2017). "Magma Mixing: History and Dynamics of an Eruption Trigger". Advances in Volcanology. Springer International Publishing, pp. 123137. DOI: 10.1007/11157_2017_30.

Nakamura, M. (1995). "Continuous mixing of crystal mush and replenished magma in the ongoing Unzen eruption". Geology 23.9, p. 807. Dor: 10.1130/00917613 (1995) $023<0807$ : cmocma>2 . 3. co; 2.

Nurmawati, A. and K. I. Konstantinou (2018). "Hazard assessment of volcanic ballistic impacts at $\mathrm{Mt}$ Chihshin, Tatun Volcano Group, northern Taiwan". Natural Hazards 92.1, pp. 77-92. Dor: 10 . 1007 / s11069-018-3192-4.

Panjasawatwong, Y., L. V. Danyushevsky, A. J. Crawford, and K. L. Harris (1995). "An experimental study of the effects of melt composition on plagioclase-melt equilibria at 5 and $10 \mathrm{kbar}$ : implications for the origin of magmatic high-An plagioclase". Contributions to Mineralogy and Petrology 118.4, pp. 420-432. DoI: $10.1007 / \mathrm{s} 004100050024$.

Papale, P., A. Neri, and G. Macedonio (1998). "The role of magma composition and water content in explosive eruptions". Journal of Volcanology and Geothermal Research 87.1-4, pp. 75-93. Dor: 10.1016/s03770273(98) 00101-2.

Paredes-Mariño, J., K. J. Dobson, G. Ortenzi, U. Kueppers, D. Morgavi, M. Petrelli, K. Hess, K. Laeger, M. Porreca, A. Pimentel, and D. Perugini (2017). "Enhancement of eruption explosivity by heterogeneous bubble nucleation triggered by magma mingling". Scientific Reports 7.1. DOI: 10 . 1038 / s41598-01717098-3.

Paris, R., H. Guillou, J. Carracedo, and F. Torrado (2005). "Volcanic and morphological evolution of La Gomera (Canary Islands), based on new $\mathrm{K}-\mathrm{Ar}$ ages and magnetic stratigraphy: implications for oceanic island evolution". Journal of the Geological Society 162.3, pp. 501-512. Dor: 10.1144/0016-764904-055.

Paulick, H., C. Münker, and S. Schuth (2010). "The influence of small-scale mantle heterogeneities on MidOcean Ridge volcanism: Evidence from the southern Mid-Atlantic Ridge ( $7^{\circ} 30 / \mathrm{S}$ to $\left.11^{\circ} 30 / \mathrm{S}\right)$ and Ascension Island". Earth and Planetary Science Letters 296.3-4, pp. 299-310. DoI: 10.1016/j . eps1.2010.05. 009. 
Perugini, D., C. P. D. Campos, M. Petrelli, and D. B. Dingwell (2015). "Concentration variance decay during magma mixing: a volcanic chronometer". Scientific Reports 5.1. Dor: 10.1038/srep14225.

Perugini, D., G. Poli, M. Petrelli, C. P. D. Campos, and D. B. Dingwell (2010). "Time-scales of recent Phlegrean Fields eruptions inferred from the application of a 'diffusive fractionation' model of trace elements". Bulletin of Volcanology 72.4, pp. 431-447. DOI: $10.1007 / \mathrm{s} 00445-009-0329-z$.

Petrone, C. M., E. Braschi, L. Francalanci, M. Casalini, and S. Tommasini (2018). "Rapid mixing and short storage timescale in the magma dynamics of a steadystate volcano". Earth and Planetary Science Letters 492, pp. 206-221. Dor: 10.1016/j .epsl.2018.03.055.

Preece, K., D. F. Mark, J. Barclay, B. E. Cohen, K. J. Chamberlain, C. Jowitt, C. Vye-Brown, R. J. Brown, and S. Hamilton (2018). "Bridging the gap: $40 \mathrm{Ar} / 39 \mathrm{Ar}$ dating of volcanic eruptions from the 'Age of Discovery'”. Geology 46.12, pp. 1035-1038. Dor: $10.1130 / \mathrm{g} 45415.1$.

Putirka, K. D. (2008). "Thermometers and Barometers for Volcanic Systems". Reviews in Mineralogy and Geochemistry 69.1, pp. 61-120. DoI: $10.2138 / \mathrm{rmg} .2008$. 69.3 .

Schmincke, H.-U. (1976). "The Geology of the Canary Islands". Monographiae Biologicae. Springer Netherlands, pp. 67-184. DoI: $10.1007 / 978-94-010-1566-$ 0_4.

Sharp, W. D. and P. R. Renne (2005). "The40Ar/39Ar dating of core recovered by the Hawaii Scientific Drilling Project (phase 2), Hilo, Hawaii". Geochemistry, Geophysics, Geosystems 6.4, n/a-n/a. DOI: 10 . $1029 / 2004 \mathrm{gc} 000846$.

Shaw, D. M. (1970). "Trace element fractionation during anatexis". Geochimica et Cosmochimica Acta 34.2, pp. 237-243. DoI: 10.1016/0016-7037(70)90009-8.

Sigmarsson, O., I. Vlastelic, R. Andreasen, I. Bindeman, J.-L. Devidal, S. Moune, J. K. Keiding, G. Larsen, A. Höskuldsson, and T. Thordarson (2011). "Remobilization of silicic intrusion by mafic magmas during the 2010 Eyjafjallajökull eruption". Solid Earth 2.2, pp. 271-281. DOI: 10.5194/se-2-271-2011.

Sigurdsson, H. and R. S. J. Sparks (1981). "Petrology of Rhyolitic and Mixed Magma Ejecta from the 1875 Eruption of Askja, Iceland". Journal of Petrology 22.1, pp. 41-84. DoI: 10.1093/petrology/22.1.41.
Sigurdsson, H. (1977). "Generation of Icelandic rhyolites by melting of plagiogranites in the oceanic layer". Nature 269.5623, pp. 25-28. Dor: 10.1038/ $269025 \mathrm{a} 0$.

Singer, B. S., F. Costa, J. S. Herrin, W. Hildreth, and J. Fierstein (2016). "The timing of compositionallyzoned magma reservoirs and mafic 'priming' weeks before the 1912 Novarupta-Katmai rhyolite eruption". Earth and Planetary Science Letters 451, pp. 125-137. Dor: 10.1016/j .epsl.2016.07.015.

Sliwinski, J. T., O. Bachmann, B. S. Ellis, P. DávilaHarris, B. K. Nelson, and J. Dufek (2015). "Eruption of Shallow Crystal Cumulates during Explosive Phonolitic Eruptions on Tenerife, Canary Islands". Journal of Petrology 56.11, pp. 2173-2194. Dor: 10 . 1093/petrology/egv068.

Smith, I. E., R. B. Stewart, R. C. Price, and T. J. Worthington (2010). "Are arc-type rocks the products of magma crystallisation? Observations from a simple oceanic arc volcano: Raoul Island, Kermadec Arc, SW Pacific". Journal of Volcanology and Geothermal Research 190.1-2, pp. 219-234. DOI: $10.1016 / \mathrm{j}$. jvolgeores. 2009.05.006.

Smith, R. L. and R. A. Bailey (1966). "The Bandelier Tuff: A study of ash-flow eruption cycles from zoned Magma Chambers". Bulletin Volcanologique 29.1, pp. 83-103. Dor: 10.1007/bf02597146.

Sparks, R. S. J., J. Biggs, and J. W. Neuberg (2012). "Monitoring Volcanoes". Science 335.6074, pp. 13101311. Dor: 10.1126 /science. 1219485.

Sparks, S. R. J., H. Sigurdsson, and L. Wilson (1977). "Magma mixing: a mechanism for triggering acid explosive eruptions". Nature 267.5609, pp. 315-318. Dor: $10.1038 / 267315 a 0$.

Weaver, B., A. Kar, J. Davidson, and M. Colucci (1996). "Geochemical characteristics of volcanic rocks from ascension island, South Atlantic Ocean". Geothermics 25.4-5, pp. 449-470. DOI: $10.1016 / 0375-6505$ (96) $00014-4$.

Wiesmaier, S., F. M. Deegan, V. R. Troll, J. C. Carracedo, J. P. Chadwick, and D. M. Chew (2011). "Magma mixing in the 1100 AD Montaña Reventada composite lava flow, Tenerife, Canary Islands: interaction between rift zone and central volcano plumbing systems". Contributions to Mineralogy and Petrology 162.3, pp. 651-669. DoI: $10.1007 /$ s00410-010-0596$\mathrm{x}$. 